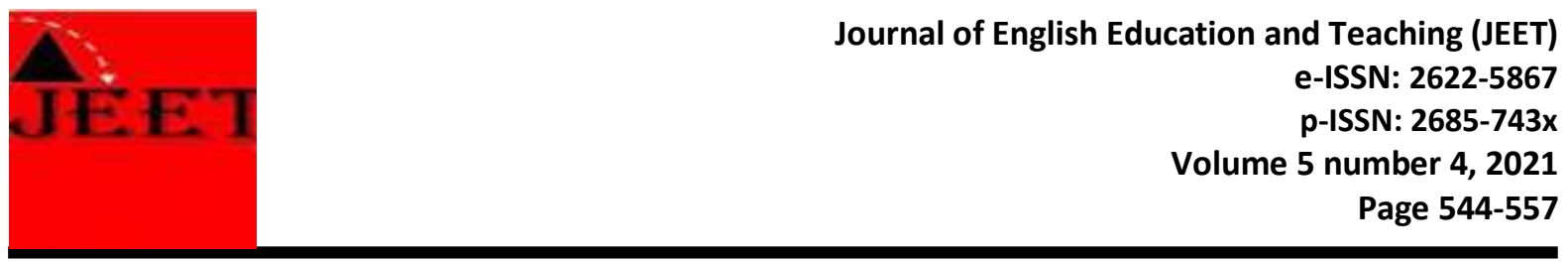

\title{
Exploiting Drama for Children in EFL Teaching to Promote Creativity, Confidence, and Motivation
}

\author{
Ahmad Ridho Rojabi \\ Universitas Negeri Surabaya \\ Universitas Islam Negeri Kiai Haji Achmad Siddiq Jember \\ email ahmadridho.21036@mhs.unesa.ac.id \\ Ali Mustofa \\ Universitas Negeri Surabaya \\ alimustofa@unesa.ac.id \\ Corresponding email: ahmadridho.21036@mhs.unesa.ac.id
}

\begin{abstract}
Creating a positive atmosphere in EFL teaching is challenging, and teachers need to identify the learners' needs, characteristics, levels and facilitate them with interesting classroom-based activities. Teachers need to create a pleasant and interactive atmosphere in the children's class to reflect on real events through the stories they play. Drama is one of the powerful tools and can be exploited to engage children in the English learning process and provide a meaningful task. By creating meaningful contexts, drama techniques help them develop their integrated linguistic competence and motivate students' interest in learning the language. This research aims to explore how drama impacts the students' confidence, creativity, and motivation to learn English. This research employed a literature review by identifying and selecting appropriate journal articles regarding drama in EFL teaching. The findings revealed that drama is beneficial in increasing students' confidence, creativity, and motivation to learn English. Teachers are suggested to exploit drama as it boosts the learners' enthusiasm to learn English effectively. Further research is recommended to conduct an in-depth investigation on drama for children either in a quantitative or qualitative approach. Students' interaction in drama activities needs to be investigated to identify how it impacts the learners' success in the drama classroom.
\end{abstract}

Keywords: drama, EFL teaching, literature review

\section{Introduction}

Literature learning at universities has been categorized into several literary genres; poetry, prose, and drama. Teaching drama is one of the more difficult literary genres for students to learn as a performing art, and it is unique in that it combines several art branches. Drama as a performing art is commonly referred to as a stage drama performed and it contains elements of the script, the production team, and the artistic (include production leader, director, cast, lighting, setting, property, and other crews), as well as the audience. The three elements have an 
important role, if one element is missing, the drama will not become a complete performing art.

Learning Drama can be classified into two groups, namely: (1) learning drama texts which include literature, and (2) drama performances which include the theater field. In learning drama (and literature), it is not only giving knowledge about the drama itself but also appreciating (affective element) and staging (psychomotor element). In brief, the cognitive, affective, and psychomotor skills are also obtained by students holistically. In staging drama, there are psychomotor, cognitive, and affective aspects. When doing the action in dramas, there will be a fusion of cognitive, affective, and emotional aspects of psychomotor. These three aspects are integrated into the actor who is doing the action (Baihaqi, 2016).

A pleasant atmosphere in the children's drama class needs to be created so that it can reflect real-life events. Children's drama must also reflect the life of the child through the stories he plays. However, learning drama as learning literature is less attractive to children in schools. Rusyana in Waluyo (2008) mentions three preferences of literary works for children are prose, poetry, and drama. The comparison is $6: 3: 1$. This is because the drama script in the form of dialogue is quite difficult to understand and students need regular time to ensoul it. In addition, children's low interest in learning drama is because teachers still use a lot of monotonous teaching methods so that children feel bored and lazy to take part in drama learning. Besides, in children's drama learning, there is a lack of intensity of the exercise to develop ideas and appreciate the role so that the child's ability to write drama texts and the ability to live the role in the drama is poor.

Drama in EFL teaching provides the following advantages: 1) acquiring meaningful and fluent interaction in the target language, 2) promoting complete assimilation of all pronunciations and prosodic features in a fully contextual and interactive manner, 3) acquiring fully contextual of new vocabulary and structures, 4) boosting learners' willingness and proficiency in the target language (Boudreault, 2010; Wessels, 1987).

Drama for children is expected to be able to introduce, guide, develop and appreciate the drama itself. Thus students will be able to enjoy, enjoy and make the drama an enjoyable part of life (Waluyo, 2008). Teachers should be able to choose learning models that are following the children's character so that they can help 
them understand drama, appreciate drama and be able to write drama texts appropriately.

Children's drama focuses on understanding the intrinsic elements of drama that have been adapted to competency standards where children must be able to identify various elements (characters, traits, setting, theme, storyline, and message) of children's drama texts. Based on competency standards, children need to identify intrinsic elements consisting of elements of building character, nature/character, plot, background/setting, theme, and message, and the discussion in understanding drama, namely: (a) Characters are actors who carry out the events in the story. Characters have a certain physical, attitude, behavior, or certain characteristics; (b) Natural behavior or character is something that arises from within a character. Characters in literary works have character. Different characters create events or conflicts that make the story more interesting; (c) Plot is a storyline that begins with an introduction, the beginning of the problem, leads to the climax, climax, and solution; (d) Setting is a description of the place, atmosphere, and time. Setting can also indicate space, time, tools, objects, clothes, systems work, and living systems related to the place where the events occur to be the background of the story; (e) Theme is the main thought. Themes must be distinguished from moral values or messages (Poerwodarminto, 1976); and (f) the message is the message what the author wants to convey from a story so that it can be remembered by the audience.

Writing drama texts is defined as learning in combining humans, material, equipment, and procedures that influence each other to achieve learning objectives (Hamalik, 2004). Drama text as one of the literary genres is built by the physical structure (linguistics) and inner structure (semantics, meaning). The physical form of a drama text is dialogue or a variety of speech. The steps for writing a drama text start from formulating a theme or idea, describing the characterizations or naming the characters, outlining the contents of the story, developing the outline of the story content into dialogues, make staging instructions which are usually written in parentheses or can be written in italics or all capital letters, and give a title to the text of the drama that has been written.

Exploiting drama in EFL teaching is challenging, teachers must ensure that the techniques developed will fit into the lesson plan in their curriculum and can answer the needs of students effectively (Gaudart, 1990). Learning materials according to students' interests are important preparations for drama activities. Do students 
understand the material sufficiently? Will the material attract their interest? Is it possible for the teacher to explore teaching materials for useful drama material? The above considerations will encourage teachers to choose the right teaching materials according to the student's level, provide meaningful tasks and create a free environment that makes students feel comfortable. In brief, a comfortable learning environment can motivate students' interest in learning the language (Davies, P., \& Pearse, 2002).

First, a quantitative study with a quasi-experimental design was conducted by Kadan (2021). The study investigated the effectiveness of creative drama on 7th graders' achievement and motivation in English courses. The results revealed that creative drama is regarded as a fascinating learning method for promoting both student achievement and motivation. However, the improvement of students' English achievement in the experimental group was not statistically significant compared to the control group.

Second, a literature review on a strong willingness to communicate (WTC) and Drama based approach (DBAs) was conducted by Lee et al. (2020). They integrate key findings to promote the implementation of dramatized role-plays that can improve students' linguistic and general academic skills while also fostering students' WTC. DBAs for English teaching could promote a positive learning environment, enhance learners' confidence, beneficial impact, motivation as well as learners' WTC.

Third, Dora To et al. (2011) conducted a qualitative study with focus group interviews after completing Drama Process Program. Five school principals, four subject committee heads, twenty-five teachers, forty students, and six parents participated in focus group interviews with six randomly selected schools. The data from the interviews revealed several positive responses in the teachers' and students' experiences. Learning becomes more relaxed and enjoyable when drama is implemented. Students are permitted to move around rather than simply sit and listen to the teacher speak. Drama not only motivates students with the numerous individual/group tasks that they must attain but also provides more opportunities for them to speak up in class confidently.

Fourth, a research article was written by Olarak et al. (2017). The study was designed around a document analysis that was evaluated in the context of qualitative research. The study was also carried out in collaboration with 32 students 
enrolled in a compulsory Drama course. The findings revealed that Nasreddin Hodja jokes can be used to create drama activities in foreign language classes. Prospective language teachers who had grown up with a cultural hero could adjust and adapt the jokes for practice and use them as drama activities in the classroom. This also made learning more enjoyable, as they were not only learning but also entertained during the activities.

Many previous studies have explored Drama in facilitating students' motivation and boosting their engagement and confidence. However, few studies have explored Drama in improving children's creativity, confidence, and motivation. Therefore, to fill in the gap, this in-depth investigation needs to be conducted to investigate the exploitation of Drama for children in EFL teaching to promote creativity, confidence, and motivation. Furthermore, the research question is "How successful is the exploitation of Drama for children in EFL teaching to promote creativity, confidence, and motivation?.

\section{Research Methodology}

In this study, the literature review method was used. It is a research method that entails gathering information from libraries or research objects such as books or journal articles. It focuses on the analysis and review of various publications by scholars or other research scholars (Taylor \& Procter, 2010). A fine source of literature must meet three criteria: relevance, completeness, and recentness. Relevance in terms of the consistency of the variables studied and the proposed theory, completeness in terms of the number of sources read, and timeliness in terms of the time domain are all important considerations. The more recent the sources used, the higher the quality of the theory.

After obtaining the sources, an analysis was performed to determine the relevance of the source to the title it possesses. Conducting literature research comprises of four steps: designing the review, performing the review, analyzing the review, and composing the review (Synder, 2019). The descriptive method was used in data analysis to create a systematic and objective description, picture, or painting of facts, properties, characteristics, and relationships between existing elements or certain phenomena (Taylor et al., 2016). 


\section{Findings and Discussion}

\section{Findings}

Several procedures were carefully conducted by the researcher. First, the researcher identified relevant studies based on the keywords that covered three aspects of creativity, confidence as well as motivation in drama by using the Google search engine. Second, the researcher selected various articles regarding drama based on the relevance, completeness as well as recentness. It is to decide whether the article can be included or not. After carefully selecting relevant and updated articles, there were seven articles regarding Drama in promoting learners' creativity, twelve articles regarding Drama in promoting learners' confidence, and eleven articles regarding Drama in promoting learners' motivation (See in Table 1, Table 2, and Table 3).

Table 1: Drama promotes learners' creativity

\begin{tabular}{|c|l|l|l|}
\hline NO & \multicolumn{1}{|c|}{ References } & \multicolumn{1}{|c|}{ Study design } & \multicolumn{1}{|c|}{$\begin{array}{l}\text { Group or } \\
\text { Individual } \\
\text { intervention }\end{array}$} \\
\hline 1 & Lehtonen, et. al. (2016) & Qualitative & Group \\
\hline 2 & Toivanen, et. al. (2014) & Qualitative & Group \\
\hline 3 & Kim (2011) & Quantitative & Individual \\
\hline 4 & Craft (2014) & Qualitative & Individual \\
\hline 5 & Fairweather \& Cramond (2010) & Qualitative & Group \\
\hline 6 & Wu et al. (2020) & Quantitative & Group \\
\hline 7 & Lin (2010) & Qualitative & Individual \\
\hline
\end{tabular}

Table 2: Drama promotes learners' confidence

\begin{tabular}{|c|l|l|l|}
\hline NO & \multicolumn{1}{|c|}{ References } & Study design & \multicolumn{1}{|c|}{$\begin{array}{c}\text { Group or } \\
\text { Individual } \\
\text { intervention }\end{array}$} \\
\hline 1 & Bas (2008) & Qualitative & Individual \\
\hline 2 & Cruz (2019) & Qualitative & Individual \\
\hline 3 & Gill (2016) & Qualitative & Individual \\
\hline 4 & Barnes (2014) & Qualitative & Individual \\
\hline 5 & Wu et al. (2020) & Quantitative & Group \\
\hline 6 & Peter (2021) & Qualitative & Individual \\
\hline 7 & Stinson (2015) & Qualitative & Individual \\
\hline 8 & Lin (2010) & Qualitative & Individual \\
\hline 9 & Astuti (2016) & Qualitative & Individual \\
\hline 10 & Asimidou et al. (2021) & Mixed-method & Group \\
\hline 11 & To et al. (2011) & Qualitative & Group \\
\hline 12 & Antonelli et al. (2014) & Qualitative & Group \\
\hline
\end{tabular}


Table 2: Drama promotes learners' motivation

\begin{tabular}{|c|l|l|l|}
\hline NO & \multicolumn{1}{|c|}{ References } & \multicolumn{1}{|c|}{ Study design } & \multicolumn{1}{|c|}{$\begin{array}{c}\text { Group or } \\
\text { Individual } \\
\text { intervention }\end{array}$} \\
\hline 1 & Schiller (2008) & Mixed-method & Individual \\
\hline 2 & Cruz (2019) & Qualitative & Individual \\
\hline 3 & Arjulayana, \& Srikandi (2019) & Qualitative & Group \\
\hline 4 & Gill (2016) & Qualitative & Individual \\
\hline 5 & Barnes (2014) & Qualitative & Individual \\
\hline 6 & Lund (2017) & Qualitative & Individual \\
\hline 7 & Celume et al. (2019) & Quantitative & Group \\
\hline 8 & Kadan (2021) & Quantitative & Individual \\
\hline 9 & Bravo et al. (2021) & Qualitative & Group \\
\hline 10 & To et al. (2011) & Qualitative & Group \\
\hline 11 & Hanrahan \& Banerjee, 2017) & Qualitative & Group \\
\hline
\end{tabular}

\section{Discussion}

Firstly, talking to creativity, drama enables learners to build creativity and gain a deeper understanding of themselves and others. They will make comparisons between the characters in the drama and their own lives in real life, implying that drama has the opportunity to alter students' perspectives on how to cope with interpersonal relationships. As reported in an article written by Lin (2010), Drama was beneficial in boosting the learners' creativity, such as imagination, independent thinking, and risk-taking. The students could identify the strategies used in the drama that enabled their improvements, such as task-oriented, collaborative learning, and the teacher's guidance and ethos. Furthermore, they also could recognize five characteristics of creative teaching in drama: playfulness, innovation, flexibility, space, and in-depth learning.

Drama teachers need to provide space and time for boosting their students' creativity. They must also be capable of making quick decisions, managing groups, tolerating incompleteness, and creating a positive learning environment. The teacher must be present holistically in order to consider students' perspectives in effective and responsive drama decision-making. Constant critical reflection and awareness of the students' agency, as well as the development of ownership, are essential components of good creative collaboration practice. It is important for teachers to provide space for students' creative processes and to integrate levels where students can successfully be involved in self-development (Lehtonen et al., 2016). 
An article written by Toivanen et al. (2014) confirms that a creative learning environment of drama provides rich experiences and active roles for the learners. Interaction becomes an essential component to create the learning process effectively. Social interaction, children's imagination, and inner motivation are aided by a creative environment. Furthermore, the atmosphere is hospitable. These elements also foster the possibility of group creativity. As reported by Kim (2011), it is crucial to consider the creative development of children at two levels: individual creativity and group creativity. through experiential, and social processes, teaching drama facilitates students' creativity.

One of the important factors in facilitating student creativity is a positive atmosphere in the classroom, which is also closely related to student-teacher interaction. It is also critical that pedagogical alternatives in the classroom focus on students' viewpoints. Several research articles reveal that a positive learning environment can encourage learners to be more active and independent. It can build the learners' creativity and help them to explore their ideas confidently (Craft et al., 2014; Fairweather, E. \& Cramond, 2010).

Secondly, talking to self-confidence, people can share opinions, culture, and views of the world through language. By participating in drama, the learners directly experience sharing and communicating with each other. However, teaching English as a foreign language is challenging, teachers need to exploit some techniques to help the learners engage in a language classroom. One of the techniques is by exploiting drama. An article written by Bas (2008) confirms that drama activities facilitate students to learn the language better because they can interact and communicate with other people even though they have a limited vocabulary. They can use their body language as well as gestures to express their goal.

Schiller (2008) suggests the benefits of exploiting drama for some students who are at risk, namely those who are slow in learning languages. How can we encourage them to participate and be involved in learning? Dramatic games or activities can encourage them to communicate with others and express themselves confidently. While there are now many online learning platforms as well as audiovisual aids for learning some common phrases and words, students need to gain real-world experience by being directly involved in the language environment or drama class. An article written by Gaudart (1990) confirms that drama was also used 
to introduce, stimulate students' interest and create their enthusiasm for learning English. By exploiting drama, students' imagination can be developed.

Furthermore, it is critical to provide second or foreign language learners with high motivation and self-confidence, which Krashen refers to as the Affective Filter Hypothesis. An article mentions that motivation and self-confidence should be placed in the first level, while anxiety should be placed in the second level when learning a second or foreign language (Cruz, 2019). Another article also mentions that motivation is considered the main aspect in learning a foreign language or a second language as it influences learners to achieve their goals (Arjulayana, \& Srikandi, 2019).

Another article was carried out by Gill (2016). He confirms that drama allows students to speak communicatively without fear of persistent revision, in a fun and comfortable learner-centered setting that emerges to help in reducing their anxiety and nervousness. As a consequence, their motivation to speak grows, resulting in longer speech production. Another research article conducted by Barnes (2014) focuses on the observation of six and seven-year-old with difficulties with speech, language, and communication by implementing the Speech Bubbles project. The result revealed that drama is effective in motivating and building children's confidence with communication difficulties.

\section{Conclusion}

Drama plays an important role in EFL teaching. This technique is very interesting to provide experience to teachers as well as students in processing English acquisition together. This technique facilitates students in improving their creativity, confidence, and motivation. For teachers, this technique is effective and challenging because it facilitates each student to become a more initiative and interactive learner in English as a first language. Further qualitative analysis is suggested to conduct an- in-depth investigation regarding the importance of drama in increasing the learners' creativity, confidence as well as motivation. A highlight on students' interaction in drama activities would also be advised to identify how it impacts the students' success in the drama classroom.

\section{References}

Antonelli, L., Bilocca, S., Borg, D., Borg, S., Boxall, M., Briffa, L., Debono, C., Falzon, R., Farrugia, V., Gatt, L., Formosa, M., Mifsud, D., Mizzi, K., Scurfield, L., Scurfield, M., 
\& Vella, G. L. (2014). Drama, performance ethnography, and self-esteem: Listening to youngsters with dyslexia and their parents. SAGE Open, $4(2)$. https://doi.org/10.1177/2158244014534696

Arjulayana, \& Srikandi, C. N. (2019). Early semester student needs in English mastery to support teaching and learning process in English department. Asian EFL Journal, $24(4)$, 78-97.

Asimidou, A., Lenakakis, A., \& Tsiaras, A. (2021). The contribution of drama pedagogy in developing adolescents' self-confidence: a case study. Drama Australia Journal, 45(1), 45-48. https://doi.org/10.1080/14452294.2021.1978145

Astuti, D. (2016). Using local drama in writing and speaking: EFL learners' creative expresssion. Journal of English Language Teaching and Linguistics, 1 (1), 51-77.

Baihaqi, I. (2016). Peningkatan keterampilan bermain drama dengan metode Role Playing pada kelompok teater Kenes SMPN 4 Yogyakarta. Transformatika: Jurnal Bahasa, Sastra, Dan Pengajarannya, 12(2), 15-28.

Barnes, J. (2014). Drama to promote social and personal well-being in six- and sevenyear-olds with communication difficulties: The Speech Bubbles project. Perspectives in Public Health, 134(2), 101-109. https://doi.org/10.1177/1757913912469486

Bas, G. (2008). Integrating multiple intelligences in ESL/EFL classroom. The Internet TESL Journal, XIV(5), 1-5. http://iteslj.org/Techniques/BasIntegratingMultiplelntelligences.html

Boudreault, C. (2010). The benefits of using drama in the ESL/EFL classroom. The Internet TESL Journal, XVI(1). http://iteslj.org/Articles/Boudreault-Drama.html

Bravo, F. A., Hurtado, J. A., \& Gonzalez, E. (2021). education sciences Using Robots with Storytelling and Drama Activities in Science Education. Education Sciences, 11 (329), 1-16. https://doi.org/10.3390/educscil 1070329

Celume, M., Besançon, M., \& Zenasni, F. (2019). How a dialogic space can impact children' $s$ creativity and mood valence in Drama Pedagogy Training: Study with a French 4th grade sample. Thinking Skills and Creativity, 33(January), 100576. https://doi.org/10.1016/j.tsc.2019.100576

Craft, A., Cremin, T., Hay, P., \& Clack, J. (2014). Creative primary schools: developing and maintaining pedagogy for creativity. Ethnography and Education, 9(1), 1634.

Cruz, A. O. de la. (2019). Surface structure taxonomy - based analysis of errors in 
written English sentences of ESL learners. Asian EFL Journal, 24 (4), 13-37.

Davies, P., \& Pearse, E. (2002). Success in English Teaching. Shanghai Foreign Language Education Press.

Dora To, L., Phoebe Chan, Y., Lam, Y. K., \& Tsang, S. Y. (2011). Reflections on a primary school teacher professional development programme on learning English through Process Drama. Research in Drama Education, 16(4), 517-539. https://doi.org/10.1080/13569783.2011.617099

Fairweather, E. \& Cramond, B. (2010). Infusing creative and critical thinking into the curriculum together. In R. Teoksessa Beghetto \& J. Kaufman (Eds.), Nurturing creativity in the classroom. Cambridge University Press.

Gaudart, H. (1990). Using drama techniques in language teaching. In Language Teaching Methodology for the Nineties (pp. 230-249). https://files.eric.ed.gov/fulltext/ED366197.pdf

Gill, C. (2016). Maximising Asian ESL Learners' Communicative Oral English via Drama. Advances in Language and Literary Studies, $7(5)$. https://doi.org/10.7575/aiac.alls.v.7n.5p.240

Hamalik, O. (2004). Proses Belajar Mengajar. Bumi Angkasa.

Hanrahan, F., \& Banerjee, R. (2017). 'It makes me feel alive': the socio-motivational impact of drama and theatre on marginalised young people. Emotional and Behavioural Difficulties, 22(1), 35-49. https://doi.org/10.1080/13632752.2017.1287337

Kadan, Ö. F. (2021). The effects of creative drama on achievement and motivation levels of the 7 th graders in English language classes. 8(August), 88-104.

Kim, K. H. (2011). The creativity crisis: The decrease in creative thinking scores on the Torrance Tests of creative thinking. Creativity Research Journal, 23(4), 285-295. https://doi.org/10.1080/10400419.2011.627805

Lee, K. K., Abbott, M., \& Chen, N. (2020). Increasing students' willingness to communicate: Drama-Based Approaches to language instruction in English for academic purposes classes. TESL Canada Journal, 37(3), 75-87. https://doi.org/10.18806/tesl.v37i3.1346

Lehtonen, A., Kaasinen, M., Karjalainen-Väkevä, M., \& Toivanen, T. (2016). Promoting creativity in teaching drama. Procedia - Social and Behavioral Sciences, 217. 558-566. https://doi.org/10.1016/j.sbspro.2016.02.046

Lin, Y. (2010). Drama and possibility thinking - Taiwanese pupils ' perspectives 
regarding creative pedagogy in drama. Thinking Skills and Creativity, 5(3), 108119. https://doi.org/10.1016/j.tsc.2010.09.001

Lund, O. (2017). Being pulled into the drama - How early childhood educators motivate children by way of bodily contact and movements. December. https://doi.org/10.12691/education-5-12-5

Olarak, D., Hoca, N., \& Tasarlanmas, D. E. (2017). Designing drama activities based on Nasreddin Hodja jokes for English as a Foreign Language (EFL) classrooms. International Journal of Language Academy, 5(October 2016), 213-224.

Peter, M. (2021). Professional development in drama with learners with special educational needs and disabilities (SEND). Support for Learning, 36(3), 421-449. https://doi.org/10.1111/1467-9604.12371

Poerwodarminto, W. J. S. (1976). Kamus Umum Bahasa Indonesia. PN Balai Pustaka.

Schiller, J. (2008). Drama for at-risk students: a strategy for improving academic and social skills among public middle students [Dominican University of California]. https://files.eric.ed.gov/fulltext/ED502068.pdf

Stinson, M. (2015). Speaking up about oracy: the contribution of drama pedagogy to enhanced oral communication. English Teaching: Practice \& Critique, 14 (3), 303-313. https://doi.org/10.1 108/ETPC-07-2015-0055

Synder, H. (2019). Literature review as a research methodology: an overview and guidelines. Journal of Bussiness Research. https://doi.org/104 333-339

Taylor, D., \& Procter, M. (2010). The literature review: a few tips on conducting it.

Taylor, S. J., Bogdan, R., \& DeVault, M. L. (2016). Introduction to qualitative research methods: A guidebook and resource (4th Ed). John Wiley \& Sons, Inc.

Toivanen, T., Halkilahti, L., \& Ruismäki, H. (2014). Creative pedagogy - supporting children's creativity through drama. The European Journal of Social \& Behavioural Sciences, 7(4), 588-605. https://doi.org/10.15405/ejsbs.96

Waluyo, H. . (2008). Drama Teori dan Pengajarannya. PT. Hanindita.

Wessels, C. (1987). Drama. Oxford University Press.

Wu, J., Chen, K., Ma, Y., \& Vomočilová, J. (2020). Early intervention for children with intellectual and developmental disability using drama therapy techniques. Children and Youth Services Review, 109(December 2019). https://doi.org/10.1016/j.childyouth.2019.104689 